\title{
The qanats of Xinjiang: historical development, characteristics and modern implications for envi- ronmental protection
}

\author{
WenJun $\mathrm{HU}^{1,2}$, JieBin ZHANG ${ }^{3 *}$, YongQiang $\mathrm{LIU}^{1}$ \\ ${ }^{1}$ Hohai University, Nanjing 210098, China; \\ ${ }^{2}$ The International Economic \& Technical Cooperation and Exchange Center, Ministry of Water Resources, Beijing 100053, \\ China; \\ ${ }^{3}$ Xinjiang Institute of Ecology and Geography, Chinese Academy of Sciences, Urumqi 830011, China
}

\begin{abstract}
In China, qanats (kan'erjing/karez) exist only in Xinjiang Uygur autonomous region, being one form of traditional irrigation technology that made great contributions to oasis civilizations. There are different opinions on the origin and date of the qanats in Xinjiang due to a lack of adequate evidences. And uncontrolled over-exploitation of groundwater by pumping wells, as well as the expansion of surface water interventions nowadays, has caused serious impacts on not only the qanats, but also local ecological environments. There exist long-time arguments on whether the qanats should be restored or preserved. This study aimed to examine the historical development, geological conditions and characteristics, and modern implications of the qanats for oasis environmental protection, and to discuss the initiatives taken by local governments. The whole Xinjiang Uygur autonomous region was included as the study area, with a specific focus on Turpan prefecture. The materials and data were obtained from literature review and governmental documentation. Based on a systematic examination of three prevailing theories on the origination of Xinjiang's qanats, it is suggested modern archaeological techniques could be good solutions to explore the origination in addition to historical records used normally. Although qanats fail to fully meet today's enormous water demands, their rich historical, cultural, ecological and environmental implications in arid areas should not be underestimated. As a cultural heritage and ecologically-friendly engineering creation, qanat systems shall be kept in good condition and function by a valuable number. Recent initiatives to protect and restore target qanat systems in Xinjiang could provide positive examples for the practices in other regions of the world where the protection and restoration of qanats or similar technologies are desired.
\end{abstract}

Keywords: arid areas; qanat (kan'erjing/karez); groundwater; environmental protection; oasis; Xinjiang

Xinjiang Uygur autonomous region is the only place in China where qanats (called kan'erjing in China and karez in central Asia) exist. There were more than 1,700 qanat systems in Xinjiang in the 1950s, with a total length of over 5,000 km (Wang, 1993). Xinjiang's qanats, along with the Great Wall and the Beijing-Hangzhou Grand Canal, have been recognized as one of China's three greatest ancient engineering projects.

Deserts and gobi account for $43 \%$ of Xinjiang's total area $\left(1.66 \times 10^{6} \mathrm{~km}^{2}\right)$, while oases account for no more than $4 \%$, and most of the rest is occupied by vast mountains (Huang, 2003). The ancient Silk Road, which crossed extensive deserts in the region, was dependent on a line of strategically situated oases hugging the Taklimakan Desert in the Tarim Basin (Hansen, 1999). Nowadays, more than 95\% of the total population and almost all the agriculture, settlements and industries in the region are concentrated in the oases (Huang, 2003). Irrigation has played a significant role in maintaining the oasis civilization in Xinjiang. Of course, qanats, as one form of traditional

Received 2011-08-25; accepted 2012-01-25

*Corresponding author: JieBin ZHANG (E-mail: zhangjb@ms.xjb.ac.cn) 
irrigation technology, made great contributions in this regard.

Local people think the history of qanats in Xinjiang can be traced back to 2,000 years ago, but different opinions exist on the origin and date of the qanats due to a lack of adequate evidences (Wang, 1993; Huang, 2003). In recent decades, qanats have been replaced by modern pumping wells to meet a sharply increasing water demand. At present, only 614 qanat systems in the whole region are in use (Liu, 2004). Uncontrolled over-exploitation of groundwater has impacted not only the qanats, but also local ecological environments.

Worldwide, some scholars introduced the qanat systems and their challenges in Afghanistan, Pakistan, Iran and Syria (Wulff, 1968; Rahman, 1981; Mclachlan, 1989; Lightfoot, 1996; English, 1998; Colburn, 2002; Wessels, 2002; ICQHS, 2008; Mostafaeipour 2010). Those in Turpan of Xinjiang were also introduced (Wang, 1993; Hansen, 1999; Zhou, 2002; Huang, 2003; Liu, 2004; Tayier, 2007; Abudu et al., 2011). Most of the researches focused mainly on the engineering description and revealed the challenges of existing qanat systems, however, current environmental and ecological protection implications and initiatives on how to properly deal with them were less discussed.

The objectives of this study were to: (1) examine the origination and developmental history of qanats in Xinjiang; (2) check the geological conditions and characteristics of these qanats; (3) evaluate and analyze the implications of qanat systems for local ecological environment under the context of recent changes and challenges with the qanats; and (4) summarize and disseminate local initiatives, including adopting modern management practices and legislation for the protection of this valuable cultural heritage.

The whole Xinjiang was included as the study area, with a specific focus on Turpan prefecture. The materials and data were obtained from literature review and governmental documentation.

\section{History of Xinjiang's qanats}

The qanat systems are found in several oases between the Taklimakan Desert and the Tianshan and Kunlun mountains in South Xinjiang, and in a few oases between the Junggar Basin and the Tianshan Mountains in North Xinjiang (Fig. 1). There were more than 1,700 qanat systems with a total length of over 5,000 $\mathrm{km}$ in Xinjiang in the 1950s, of which, 1,237 were in the Turpan Basin and 437 in the Hami Basin (Wang, 1993). A small number were found in Pishan county of Hotan prefecture and Kuche county of Aksu prefecture in South Xinjiang, and in Qitai and Fukang counties of Changji Hui autonomous prefecture in North Xinjiang. Several abandoned qanat systems were also found in Kashi and near the northern piedmont of Kunlun Mountains in southwestern Xinjiang (Huang, 2003). According to the "Implementation Plan of the Xinjiang's Qanat Protection Programme” produced by the Xinjiang Cultural Relic Protection Bureau, 1,473 qanat systems existed in Xinjiang, most of which were located in the Turpan and Hami basins.

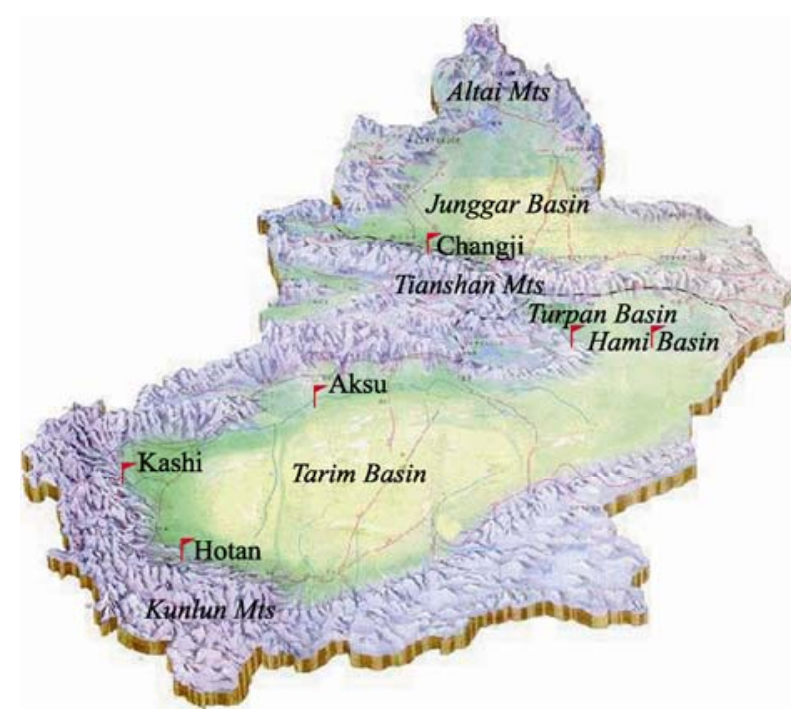

Fig. 1 Distribution of qanat systems in Xinjiang Uygur autonomous region of China. The red flags denote the sites where qanats can be found.

Few historical documents recording the early history of Xinjiang's qanats are available, which has led to national and international debates over their origin and date. Three main theories on the origin of Xinjiang's qanat technology have been offered: (1) They developed from inland Chinese shaft/tunnel technology; (2) They were imported from Central Asia /Persia; 
and (3) They were created by local minorities (Tayier, 2007).

The first theory was based on historical records on shaft/tunnel construction technology used by the ancient Chinese. SI MaQian, a great historian in the Han Dynasty (206 BC-220 AD) recorded in his work Historical Records: River and Canal Volume that shaft/tunnel technology was adopted in the Longshouqu Canal (located in modern-day Chengcheng county of Shaanxi province) excavation project from 128 BC-117 BC. In that project, an underground canal (tunnel) with a length of more than $5 \mathrm{~km}$ was excavated under a hill of $40 \mathrm{~m}$ high with the help of vertical shafts (like those in qanats) to convey canal water from one side to another side of the hill (Wang, 1993). The structure and technology of this project were very similar to those of Xinjiang's qanats. The Han Dynasty was a period when, with the opening of the Silk Road, irrigation engineering technologies gradually spread from inland China to the current Xinjiang region (Li, 2005). Based on this historical record, some Chinese scholars asserted the qanats in Xinjiang might have originated from the shaft/tunnel technology, introduced to Xinjiang by ancient Han Chinese during their migration into the region in the early Han Dynasty (Wang, 1993; Zhong, 1995; Li, 2005).

Water transported by the tunnels described above was surface canal water, not groundwater. Another record related to the technology was from a book entitled Han Dynasty History. It described a shaft/tunnel system discharging spring water was witnessed by a Han army official in Bailundui (near the Turpan Basin) of Xinjiang in 53 BC while working in the area (Zhou, 2002), but it was argued that the water extracted by the system could not simply be asserted as groundwater (Huang, 2003). No other early records on the application of shaft/tunnel technology and relevant systems in Xinjiang can be found. In contrast, some early historical records indicate that canal irrigation in East Xinjiang (including areas currently known as the Hami Basin, Turpan Basin, Lop Nur and Kuerle) was implemented in around 101 BC by Han armies stationed there as self-sufficient grain providers (IWHR, 1987; KRG, 1990; Li, 2005).

Similar shaft/tunnel technology was mentioned in some historical documentation from the Tang Dynasty (618 AD-907 AD) and Yuan Dynasty (1271 AD-1368 AD) (Zhou, 2002), but details regarding the technology and its application in Xinjiang were absent.

There was no further documentation on Xinjiang's qanats until the $18^{\text {th }}$ century, the Qing Dynasty (1644 AD-1911 AD). Almost all the records on the qanat systems during this period referred to Turpan. It seems that the earliest record mentioning qanat irrigation used in Turpan was a local official document from the year 1807, which indicates the area irrigated by qanats at that time was no more than one fifth of that irrigated by canals in Turpan (Huang, 2003).

When LIN ZeXu (a general banished to Xinjiang after the first Opium War) arrived in Turpan in 1844, about 30 qanat systems were reported to be under the management of the local government. LIN ZeXu was impressed by the systems and named them "Kajing”. Under his leadership, more than 60 additional qanats were built in Turpan by 1845 (Huang, 2003). A large subsequent expansion of qanats in Turpan was conducted by General ZUO ZongTang after his successful rebel suppression in Xinjiang in 1877 . He reported to the Qing Dynasty government in 1880 that an additional 185 "kan'erjing” systems had been built in Turpan. This seems to be the first time the Chinese name "kan’erjing” appeared in official documentation.

It was generally thought that Turpan had the longest history of qanats in Xinjiang, but Huang (2003) studied four abandoned qanat systems in the Kashi region (found in 1982) and suggested that these four systems may have an earlier date than Turpan's existing qanats. Based on Tang Dynasty relics buried under the qanat ruins in Kashi, the origin is possibly during the Halahan Dynasty in the $9^{\text {th }}$ century. Except for Kashi, existing and abandoned qanat systems in areas outside Turpan, including Kuche, Hami, Qitai, Fukang and Pishan, were all constructed in the $19^{\text {th }}$ century and afterward. Also, the technology of those qanats was spread from Turpan. As for the earliest date of the qanat systems in Turpan, many different views exist (from 300 to 1,000 years ago). These arguments are based on the oldest qanat in Turpan and some buried qanat systems found in the 1950s (Wang, 1993). All estimation on the origination date still lacks reliable 
evidence.

The second theory prevails internationally. This theory asserts that Xinjiang's qanat technology was imported from Persia along the Silk Road and refined locally (Rahman, 1981; Hansen, 1999; Mostafaeipour, 2010). The ancient Silk Road linked China to the Roman Empire via Xinjiang, Central Asia, and the Middle East after the $2^{\text {nd }}$ century BC. Trading along the Silk Road reached its peak during the Tang Dynasty. The earliest qanat technology originated in Persia (today's Iran) about 3,000 years ago (Wulff, 1968), and spread to Afghanistan approximately in the $4^{\text {th }}$ century BC (Colburn, 2002). In around the $7^{\text {th }}$ century AD, the technology spread from Afghanistan to Pakistan (Rahman, 1981), where qanats are known as "karez". It seems possible that the qanat technology diffused from Afghanistan or Pakistan to the nearby Kashi area of Xinjiang during the Halahan Dynasty in the $9^{\text {th }}$ century AD, when the Halahan Dynasty had close relations with Middle-west Asia. The pronunciation of "kan'erjing" in Xinjiang Uygur language similar with "karez" was also used by some Chinese scholars to support the second theory.

The third theory asserts that the qanat system in Turpan area was most likely a local innovation developed by the indigenous people from the long-term practices of groundwater exploitation, including tunneling, spring digging and expanding, as a response to local physical, topographical and hydrological conditions. The Kan'erjing Research Group (1990) asserted that the qanats were created by local people more than 2,600 years ago, based on some rock art found at the qanats in the Turpan Basin. Other scholars also hold that qanats were developed in parallel time but in different places, such as ancient Persia and other parts of the world (Abudu et al., 2011).

Similar conditions in precipitation, topography and hydrogeology, as well as regional geographical convenience for close communication in the past may have created the possibility for qanat technology to diffuse from Afghanistan or Pakistan to Kashi and even further to other regions in Xinjiang. The abandoned qanats in Kashi have a different style from those in Turpan. The diameters of the shafts range from 4 to $20 \mathrm{~m}$ (Huang, 2003). Moreover, the qanats in Turpan have a better developmental form than those abandoned in Kashi. The earliest relationship between them needs to be further studied to reveal their approximate dates and possible origins. Meanwhile, the first theory, based on historical documentation of over 2,000 years ago, requires more evidences, especially early ones. The existing historical documentation showed that the Chinese name of "kan'erjing" was first officially recorded in the 1880s, so it is unadvisable for some scholars to use it in supporting the first theory. The third theory lacks convincing evidence in local language records. Many terms for qanat construction methods and tools are in Chinese rather than in the local language.

\section{Characteristics of qanat systems in Xinjiang}

\subsection{Precipitation and evapotranspiration}

All areas with qanat or karez systems (like Iran, Afghanistan, Pakistan and Syria) have an average annual precipitation of no more than $300 \mathrm{~mm}$ (Rahman, 1981; Mclachlan, 1989; Lightfoot, 1996). In Xinjiang, the average annual precipitation is less than $250 \mathrm{~mm}$ in the north, no more than $80 \mathrm{~mm}$ in the south, and less than $20 \mathrm{~mm}$ in Hami and Turpan in the east. The potential evapotranspiration reaches 1,600-2,200 mm/a in the basins (Wang, 1993) and is as high as 3,000 $\mathrm{mm} / \mathrm{a}$ in Turpan (Rao, 2004), so snowmelt from high cold mountains becomes the main water source for human uses and natural needs.

People in the oases were entirely dependent on irrigation in the past. Compared to surface irrigation, qanats can avoid high water losses from evapotranspiration as well as seepage into the very dry and coarse ground surfaces, so they can transport water to further distances.

\subsection{Topography and hydrogeology}

Qanat systems require favorable topographical and hydrogeological conditions. Most preserved qanat systems usually run across relatively flat terrains, adjacent to high mountains with rich snowmelt. When valley streams flow along the flood plains and across the uplands of the alluvial fans, a large amount of water infiltrates into the coarse gravel and sand deposits on the alluvial fans at the margins of the highlands. Most of the water is recharged from the alluvial aqui- 
fers and comes as the water sources for the qanats. The qanat systems generally tap into alluvial fans to extract groundwater. Some of the qanats head into the margins of large, natural streams flowing downwards the mountains by more than $10 \mathrm{~km}$, while others connect to paleaostream banks with groundwater outcrops, and the rest link to the ends of artificial canals.

A common characteristic of qanats is that almost all the water sources are from shallow groundwater that has a close hydrological transformation relationship with surface water.

Three typical types of qanats were classified in terms of hydrogeological and recharging conditions by the Xinjiang Water Conservancy Bureau and Xinjiang Hydraulic Engineering Society. The first is related to piedmont groundwater recharge, with a small water collection created by direct interception of lateral groundwater seepage from mountain fronts. The second concerns mountain stream and valley groundwater recharge, with a larger groundwater collection and water yield capacity, and is widely distributed in the Turpan and Hami basins. The third involves plain groundwater recharge, being mostly found in irrigational areas covered by soil and with a relatively lower water yield capacity.

Figure 2 shows the topographical features of Turpan and surrounding areas where the majority of existing Xinjiang qanat systems are concentrated. With most of its land below sea level, the Turpan Basin is the second deepest inland depression in the world. However, it has a striking characteristic in that there is a great difference in altitude because it is an intermountain faulting basin of the Tianshan Mountains. At the center of the basin, the Aiding Lake has an altitude of -154 m.

The Turpan Basin has special hydrogeological features favorable for the building of large qanat systems. The basin has high temperatures and scare precipitation, and is extremely dry. With a maximum summer temperature of more than $40^{\circ} \mathrm{C}$, it earned its name "Land of Fire". The climate in the mountains in the north and western parts of the basin are cold and wet. Once summer arrives, vast amounts of snowmelt flow down in streams, and most of the water seeps into coarse gravels while the streams flow across an 8-10 $\mathrm{km}$ wide gobi belt with a relatively steep slope. Both the surface runoff and groundwater flow towards the lower basin areas. This provides rich water sources for the lower basins that are mainly covered with fine sand and loess soil. With an altitude of about $800 \mathrm{~m}$ and located at the northeastern edge of the basin, the Flaming Mountain intercepts part of the groundwater

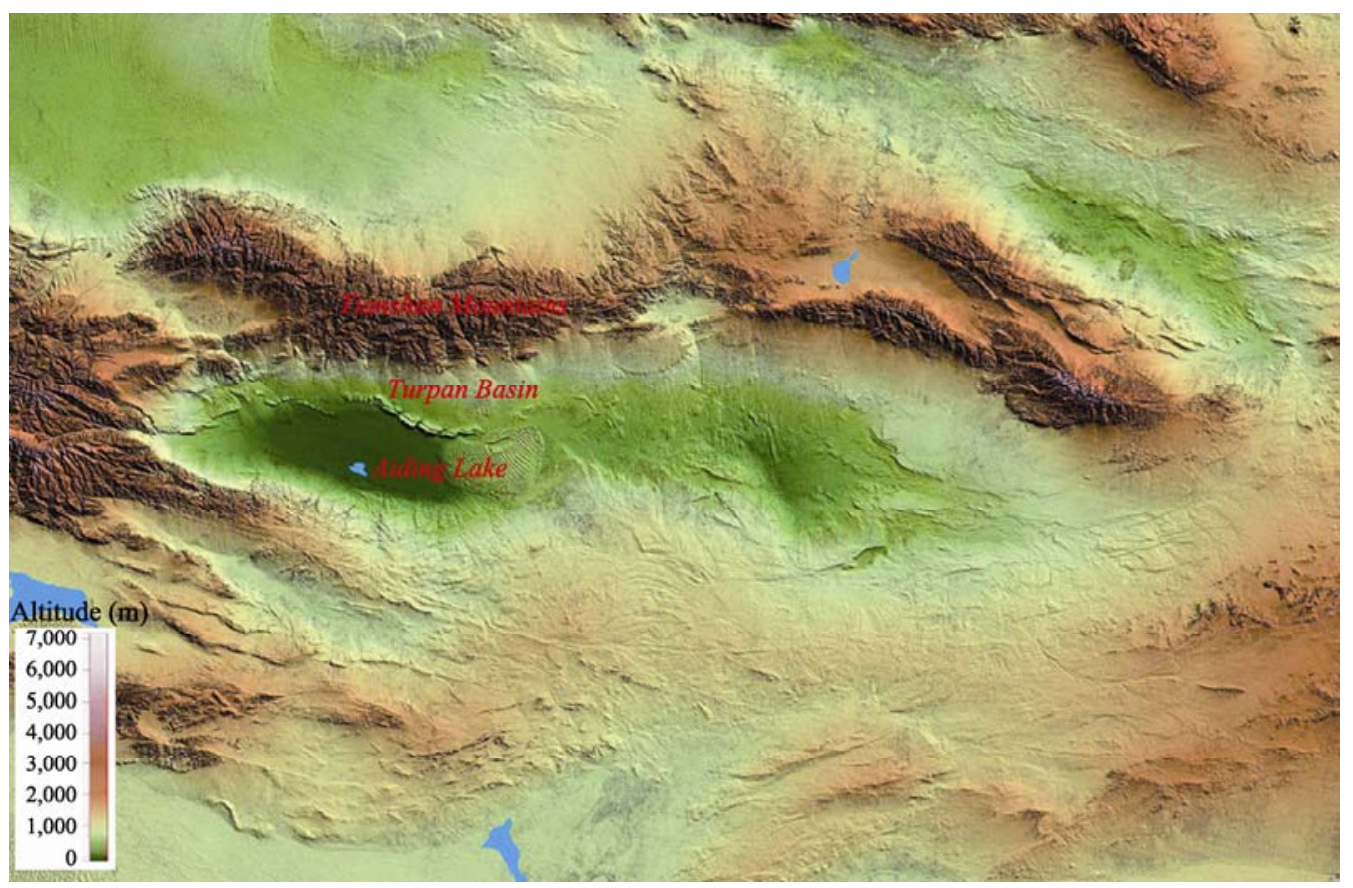

Fig. 2 Topographical conditions contributing to qanat systems in Turpan and surrounding areas (source: www.godeyes.cn) 
recharged into the gravel layers of the gobi belt and raises the groundwater table. As a result, many springs flow out into the northern foot of the mountain, then run through hills and valleys, and ultimately seep into the alluvial fans. The qanat systems in the Turpan Basin generally tap groundwater from the northern and northeastern alluvial fans and transfer it to the lower basin areas towards the Aiding Lake.

\subsection{Components and construction}

A qanat system generally consists of four components: vertical shafts, tunnels, open channels, and ponds. Figure 3 shows a general schematic for a qanat system.

The infiltration section of a tunnel is the groundwater collection section, where the groundwater table is located, so groundwater can seep into the tunnel to provide a water source for the system. The vertical shafts in the infiltration section are also called mother wells and are dug first to explore the aquifer. The initial digging of the mother wells is usually located at the outcrops of rich springs, which are locally called the Digging Springs, the Expanding Springs and the Extending Springs in order.

Once the mother wells are successfully located, an array of vertical shafts are constructed along the downslope of the alluvial fan to align the tunnels, provide ventilation and facilitate future maintenance (e.g. cleaning silt sediment). The interval between two adjacent shafts generally ranges from 60 to $100 \mathrm{~m}$ in the upper section, 30 to $60 \mathrm{~m}$ in the middle section and 10 to $30 \mathrm{~m}$ in the lower section. The diameter of the shafts is about $1-1.5 \mathrm{~m}$. The depth decreases progressively downward the slope, generally ranging from 40 to $70 \mathrm{~m}$ in the upper section (a maximum of $100 \mathrm{~m}$ as it can be), 20 to $40 \mathrm{~m}$ in the middle section and 3 to 15 $\mathrm{m}$ in the lower section (Wang, 1993).

The conveyance section of a tunnel is used to transport collected groundwater to low soil surfaces adjacent to farmlands. The length of the tunnel varies from 3 to $5 \mathrm{~km}$, and the longest in Xinjiang is more than $10 \mathrm{~km}$ (Tayier, 2007). The tunnel has an appropriate slope gradient to ensure water transport by gravity. The tunnel gradient mainly depends on soil conditions, and is normally less than that of the slope on the ground. The inner size of a tunnel shall be large enough so that the tunnel can accommodate at least one person for excavation operation. The cross section

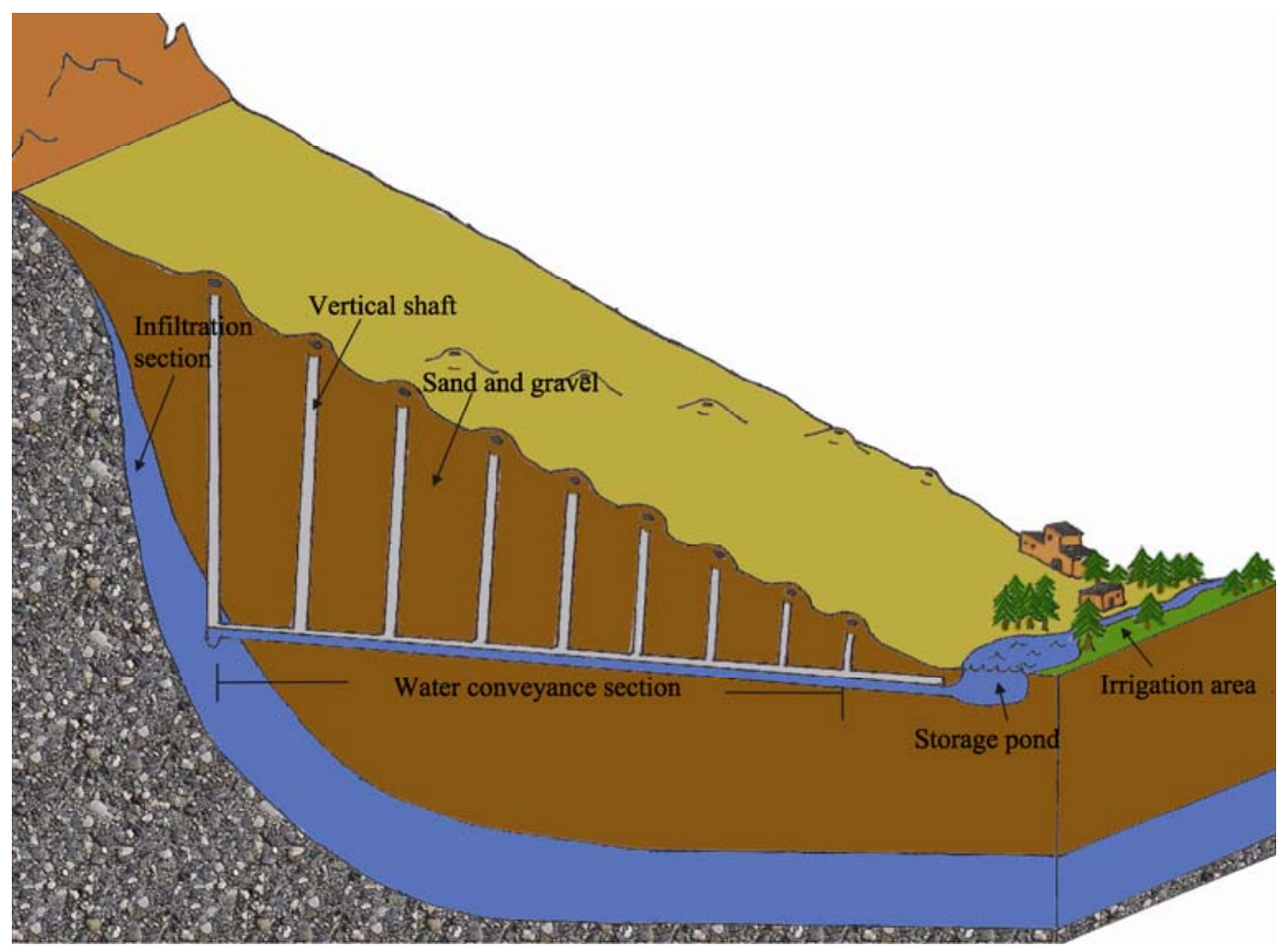

Fig. 3 General schematic for a qanat system (source: www.farwestchina.com) 
of many tunnels is oviform, about $2 \mathrm{~m}$ high and $1 \mathrm{~m}$ wide, but existing old tunnels remain in irregular shapes (Wang, 1993).

Once the vertical shafts are completed, they are connected by a single tunnel. The excavation tools are mainly a mattock and short-handled spade. A windlass is usually installed at the mouth of the shaft. Workers on the surface, with the help of the windlass, raise a bucket loaded with silt unearthed by an underground worker. A cow is sometimes used to raise the bucket, especially in the case of a deep excavation. The silt sediments are usually piled around the mouth of the shaft to prevent floodwater intrusion. In most cases, tree branches, crop straws, etc. are used to cover the mouth of the shaft to prevent sandstorm intrusion and icing.

The outlet of a tunnel is also called the dragon mouth, which connects to an open channel to transfer the groundwater to nearby farmlands. Small ponds are often constructed at the end of the open channels to store water.

Figures 4 and 5 show clear pictures of a qanat tunnel construction scene and qanat systems linking to an oasis.

\section{Recent changes, challenges and im- plications for environmental protec- tion}

The qanat technology application in Xinjiang has been declining rapidly since the 1960s. The number of qanat

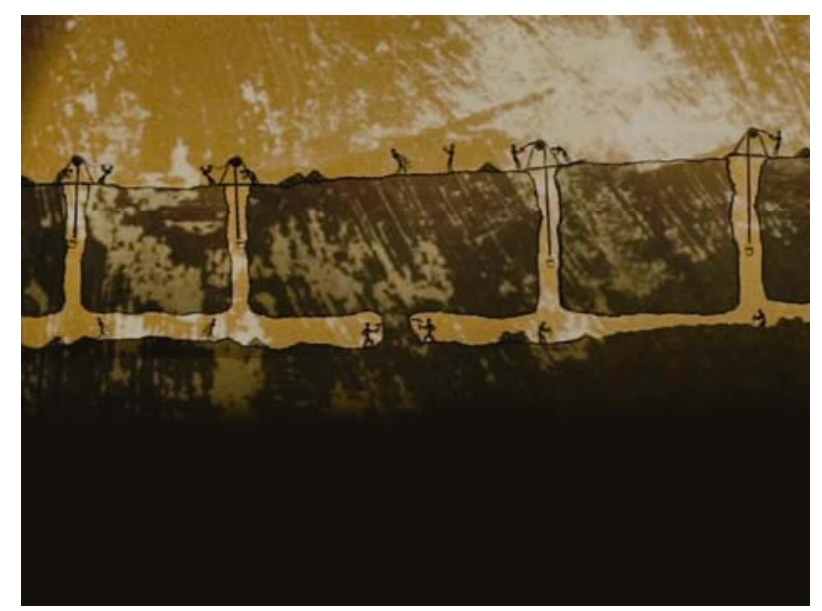

Fig. 4 Construction of a qanat tunnel (source: picasaweb.google. com)

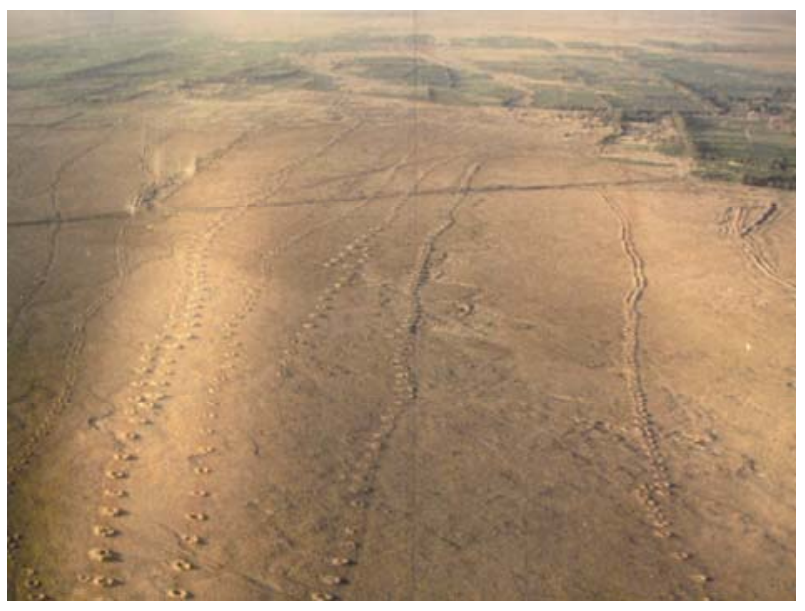

Fig. 5 Turpan oasis and qanats (source: picasaweb.google. com)

systems in function decreased from more than 1,700 in the 1950 s to around 1,100 by 1990 (of which 1,034 were in Turpan and Hami areas), and further reduced to 614 by 2004 (of which 404 were in Turpan) (Wang, 1993; Liu, 2004). As a result, the annual water yield and irrigated area related to qanats declined, respectively, from $680 \times 10^{6} \mathrm{~m}^{3} / \mathrm{a}$ and more than $20 \times 10^{3} \mathrm{hm}^{2}$ in the 1950 s to $298 \times 10^{6} \mathrm{~m}^{3} / \mathrm{a}$ and $7.3 \times 10^{3} \mathrm{hm}^{2}$ in the early $21^{\text {st }}$ century (Liu, 2004). In Turpan, the proportion of area irrigated by qanats decreased sharply from more than $70 \%$ to less than $20 \%$ over the same period (Liu, 2004). By 2009, only 238 out of the existing 1,079 qanat systems in Turpan were continuing to function.

The key factors causing the decrease of qanat water use include the construction of large reservoirs, water diversion projects, and the introduction of pumping wells. According to experts from the Xinjiang Qanats Research Association, about 909 of the 1,170 qanat systems abandoned during the past half century dried up as groundwater tables fell below tunnel levels. The upper valley stream impoundment and abstraction has reduced the amount of water recharging to the downstream alluvial aquifers. Uncontrolled well pumping has also led to the rapid falling of groundwater tables. Due to rapid population growth, the cultivated area in Turpan has expanded from $16 \times 10^{3} \mathrm{hm}^{2}$ in the 1950 s to $80 \times 10^{3} \mathrm{hm}^{2}$ in the early $21^{\text {st }}$ century (Wang, 2003). The limited water provided by qanat systems as well as irrigation canals cannot meet the rapidly increasing water demands, so wells have become an indispensa- 
ble solution for local people. Before the early $21^{\text {st }}$ century, there were more than 9,000 pumping wells in the Turpan area, installed in a maximum depth of up to 250 m (Wang, 2003; Liu, 2004). On the other hand, the collapse and block of qanat tunnels, due to weak maintenance, is also a factor to the abandonment of some qanat systems. Some disadvantages with qanats (such as limited water abstraction, high cost of and great danger in maintenance, and waste of water in winter) make local people prefer pumping wells.

The continuous over-exploitation of water resources and decreasing groundwater tables in many areas of Xinjiang have not only led to the drying up of qanat systems but also considerable impacts on regional ecology and environment. It was estimated that the desert area in Xinjiang had increased by $34 \times 10^{3} \mathrm{~km}^{2}$ from the 1950s to the 1980s, and many oases had been covered by expanding deserts (Huang, 2003). In the Turpan Basin, vast farmlands have been in the process of salinization and desertification over the past few decades. Large quantities of shrubbery around the Aiding Lake were near extinction (Liu, 2004). Meanwhile, the groundwater quality in the lower reaches of the irrigation districts of Turpan has further deteriorated. Water abstracted from wells deeper than $100 \mathrm{~m}$ has high alkali concentration, making it unsuitable for either drinking or irrigation. As a result, many farmlands have to be abandoned, and farmers were forced to migrate out.

The over-exploitation of water resources will remain to be a problem. As a mainstay industry of Turpan, grape planting is expected to expand in area (Liu, 2004). In addition, the oil industry will use more groundwater (Wang, 2003). All these imply that more groundwater will be abstracted, which will certainly lead to greater threats on the survival of existing qanat systems, yet local water management authorities have no detailed data on groundwater monitoring. The general secretary of the Xinjiang Qanat Research Association warned that all the remaining qanat systems might dry up within 25 years if no effective measures are to be adopted to protect them (Liu, 2004). Undoubtedly, this situation will have much more serious impacts on the fragile oasis ecology and environment.

\section{Initiatives for protecting qanat heritage}

Facing the gradual deterioration and abandonment of the qanat systems, there are two opposite public views on their future in Xinjiang. Arguments have lasted for a long time on if they need to be preserved.

The first view, which prevailed in most of the 1960s and 1970s, doubted whether the investment to restore and reinforce qanats is worthy of the social and economic benefits. Its main argument is that using qanats as a conventional irrigation method can not support the large irrigation required for an increasing population due to its shortcomings, such as unstable flows in irrigation periods and little reserve during non-irrigation periods. This setting often leads to unexpected water waste in such arid environments.

The second view, offered by senior water conservancy experts in the 1980s, argued that the qanat systems should be improved and used rationally to settle the conflicts between the rapid development and limitations of the system. Various measures for protecting qanat systems were suggested, including lining storage ponds, channels and the conveyance section of tunnels, and applying advanced irrigation technologies to farmlands to improve water use efficiency. Restoring some existing qanat systems back to good conditions was also suggested (Liu, 2004). It was also recommended to restrict the construction of pumping wells within the source zones of the qanat systems targeted for protection. In fact, over abstraction of the groundwater in the downstream reaches as well as surface water from upstream greatly affects the survival of the qanat systems. Measures will only be effective when the water balance and the ecological and environmental security are considered on a whole regional level.

A qanat theme park was built in Turpan to disseminate the culture of qanats as a heritage. Visitors can enter an underground tunnel to get an actual perception of the qanat technology. Special ethical cultural programs relevant to the qanats are also performed during tour seasons. The park has become famous, attracting around $1.3 \times 10^{6}$ visitors annually. This certainly promotes the appreciation of qanat technology not only for its functions and history, but also in its implicated importance of sustainable water utilization 
and ecological and environmental protection for thousands of years of oasis civilization in the vast arid areas.

Since the late 1990s, the Turpan and Hami water authorities have devoted themselves to protecting existing qanat systems with the support from the Xinjiang regional water authority. An important initial step was to carry out a thorough investigation and preparation of inventories for the existing qanat systems so as to take further sound actions. The systematic, historical and hydrological investigation started in 2002 and was completed in 2005, conducted by Xinjiang Water Resources Bureau with updated means and technology. The results included detailed information of each qanat system, including the name, location, year, wellhead, overall length, total number of vertical shafts, flow climax in history, and current flow.

Special plans on protecting and utilizing qanat systems were prepared by the local water authorities based on the above investigation results. The Plan on Conservation of Xinjiang's Qanats was approved by the central government of China in 2006, funded with $250 \times 10^{6}$ RMB yuan (Tayier, 2007). This plan aimed to put a target of 480 qanat systems across Xinjiang under thorough protection within nine years. About 250 qanats drying out were aimed to be rescued and rehabilitated for the first phase, and 115 in better conditions were to be well maintained, while 89 completely dry were to be recovered for the second phase. The funds were usually allocated by the local governments to support farmers or their collective economic organizations to conduct the rehabilitation and regular maintenance of the target qanat systems. Guidance from the government or professional institutions using modern technologies is necessary and important to ensure their successful operations.

In the past, a lack of special legislation for the protection of qanats in Xinjiang often left the management and preservation interventions unbacked in terms of administration, resources and enforcement. A specific regulation is absolutely necessary if the qanats were to be effectively and permanently protected and managed.

Fortunately, the Regulation on Protection of Qanats in Xinjiang was legally adopted by the Xinjiang People's Congress on 29 September 2006 and entered into force on 1 December, 2006 (XPC, 2006). The Regula- tion includes 36 articles and was enacted to lay a legal foundation for effectively protecting qanats as a "green" water-diversion engineering project for all of Xinjiang. The Regulation emphasizes that the protection of qanats shall be integrated with modern water use; scientific planning and comprehensive utilization shall be followed; and all the economic, social and ecological benefits shall be taken into consideration in a coordinated manner. The Regulation plays a significant role in promoting the effective undertaking of various management and protection measures on the qanats in Xinjiang. In 2006, qanat groundwater engineering was listed a national key heritage protection unit by the State Council of China, and $60 \times 10^{6} \mathrm{RMB}$ yuan was granted to rehabilitate a total of 100 qanat systems. Now the targeted qanat systems are recovering under plan, and are being applied for coverage in World Intangible Cultural Heritage Listing.

\section{Conclusions}

Existing records of the early history and development of Xinjiang's qanats are very limited, resulting in an uncertainty of their origin and date. The theory claiming that the qanat technology was possibly spread from Afghanistan or Pakistan faces the challenge of explaining the importing date and further diffusions of qanats in Xinjiang. The theory claiming the qanats originated and developed from ancient Chinese shaft/tunnel technology also needs more supportive evidence of its earlier application in Xinjiang. Aside from historical records, modern archaeological techniques including ${ }^{14} \mathrm{C}$ dating could be a good solution.

Later historical documentation proved that qanat irrigation had expanded from the $19^{\text {th }}$ century to the mid- $20^{\text {th }}$ century. In Turpan, the first official record of "kan'erjing” in Chinese was in the 1880s. The number of qanat systems in Xinjiang reached more than 1,700 in the 1950s when the area irrigated by qanats took up more than $70 \%$ of the total cultivated area in the Turpan Basin.

Xinjiang's qanats have been in a rapid decline, replaced by pumping wells over the last half century, which mainly resulted from the disadvantages in using a qanat to augment the water supply for large-scale irrigation when compared to modern irrigation tech- 
nologies. They may face a fate of disappearance in the near future, which is a scenario that is being played out in Iran, Afghanistan, Pakistan, Syria and many other places where qanats/karezs are still in use. Nevertheless, their rich historical, cultural, ecological and environmental implications in arid areas should not be underestimated. It is of no sense to debate over whether all the existing qanat systems should be restored and rehabilitated and it is not wise to solely depend on ancient solutions to meet today's enormous water demand. As a cultural heritage and ecologically-friendly engineering creation, however, qanat systems shall be kept in good condition and function by a valuable number.

Recent initiatives to protect and restore target qanat

\section{References}

Abudu S, Cevik S Y, Bawazir S, et al. 2011. Vitality of ancient karez systems in arid lands: a case study in Turpan region of China. Water History, 3(3): 213-225.

China Institute of Water Resources and Hydropower Research (IWHR). 1987. China Water History III. Beijing: Water and Hydropower Press, 417-418.

Colburn M. 2002. The many faces of Afghanistan. Portland: Mercy Corps, 35-37.

English P W. 1998. Qanats and lifeworlds in Iranian plateau villages. Yale F\&ES Bulletin, 103: 187-205.

Hansen RD. 1999. Karez (Qanats) of Turpan, China. DIALOG. [2007-11-16]. http://www.waterhistory.org/histories/turpan/turpan.pdf.

Huang S Z. 2003. Oasis Studies. Beijing: Science Press, 3-17; 246-80.

International Center on Qanats and Historic Hydraulic Structures (ICQHS). 2008. History of karezes. DIALOG. [2008-03-24]. http://www.karez. nfo/ n/history.php.

Kan’erjing Research Group under Xinjiang Hydraulic Engineering Society and Xinjiang Water Conservancy Bureau (KRG). 1990. A Study on Xinjiang's Kan'erjing. Xinjiang Water Resources Science \& Technology, 5: 32-37.

Lightfoot D R. 1996. Syrian qanat Romani: history, ecology, abandonment. Journal of Arid Environments, 33: 321-336.

Li J C. 2005. A study on the origin and date of Xinjiang's Kan'erjing. Journal of Xinjiang Normal University: Social Sciences, 26(3): 25-28.

Liu H. 2004. The "Underground Great Wall” may disappear in 25 years? -Urgent Crying for Help to Xinjiang Kanrejing. Xinhuanet News. [2010-07-25].http://big5.xinhuanet.com/gate/big5/www.xj.xinhuanet. com/2004-12/24/content_3452840.htm.

Mclachlan A. 1989. Qanat, Kariz and Khattara: Traditional Water Systems in the Middle East and North Africa. Wisbech, Cambridge- systems in Xinjiang indicate they are still playing an important role in local sustainable development, especially disseminating ecological and environmental protection implications. Lessons learned from the management and protection of Xinjiang's qanats could provide positive examples for the practices in other regions of the world where the protection and restoration of qanats or similar technologies are desired.

\section{Acknowledgments}

The authors would like to thank the anonymous reviewers for their valuable and constructive comments that have contributed to the final form of this paper. The editors of the Journal of Arid Land shall also be thanked for their responsible work.

shire, England : Middle East \& North African Studies Press, 10-35.

Mostafaeipour A. 2010. Historical background, productivity and technical issues of qanats. Water History, 2: 61-80.

Rahman M. 1981. Ecology of karez irrigation: A case of Pakistan. Geojournal, 5(1): 7-15.

Rao S. 2004. Xinjiang Kan'erjing - the Source of Oasis. Geography Education, China. [2010-07-25]. http://www.gszj.org/Article_Show.asp?ArticleID=212.

Tayier A. 2007. An overview of the studies on Xinjiang's Kan'erjing. Western Regions Studies, 1: 111-115.

Wang H T. 1992. Research on Kan'erjing in Xinjiang. Xinjiang Water Resources, 3: 11-18.

Wang H M. 2003. What Fate for Xinjing's Kan'erjing?. The People’s Daily, China. [2010-07-25]. http://www.chinawater.com.cn/newscenter/shmt/ 20031227/200312270011.asp.

Wessels J, Hoogeveen R J A. 2002. Renovation of karezes in Syria. In: Zafar Adeel. Sustainable Management of Marginal Drylands, Application of Indigenous Knowledge for Coastal Drylands. Proceedings of a Joint UNU-UNESCO-ICARDA International Workshop, Alexandria, Egypt. Tokyo, Japan: United Nations University, 1-13.

Wulff H E. 1968. The qanats of Iran. Scientific American, 218(4): 94-105.

Xinjiang People's Congress (XPC). 2006. Regulation on Protection of Kan'erjing in Xinjiang Uygur autonomous regions. The National People's Congress (NPC) of the People's Republic of China. [2010-07-25].http://www.npc.gov.cn/npc/xinwen/dfrd/xinjiang/2006 -12/05/content_354751.htm.

Zhong X Q. 1995.The shaft-tunnel method in the Central Plains and Kan'erjing in Turpan. Western Regions Studies, 4: 36-43.

Zhou K Y. 2002. Water Volume, China Science and Technology History. Beijing: Science Press, 368-370. 